\title{
Vitamin A and protein interrelationships in the milk-fed lamb
}

\author{
By O. FARUQUE* AND D. M. WALKER \\ Department of Animal Husbandry, University of Sydney, Australia
}

(Received I3 Fanuary I969-Accepted I fuly 1969)

\begin{abstract}
I. The mean liver retinol reserve (retinol + retinyl esters, expressed as retinol) of six new. born lambs was $2 \mathrm{I} \pm 8 \mu \mathrm{g}$. The mean value for ten suckled lambs, aged 5-7 days, was $2655 \pm 472$ $\mu \mathrm{g}$ retinol per liver.

2. Three unsuckled lambs were fed ad lib. from birth for 28 days on a high-protein diet, based on lard and skim milk, without supplementary vitamin A. The diet provided sufficient vitamin A for normal growth, but insufficient to permit substantial liver reserves $(43 \pm 8 \mu \mathrm{g}$ retinol per liver).

3. Thirty-six suckled lambs aged 5-7 days were given either a low-or a high-protein diet for $2 \mathrm{r}$ days, with or without graded levels of retinyl acetate or $\beta$-carotene. There were no significant differences in the live-weight gain or in liver retinol reserves between the low- and highprotein dietary treatments, or between the supplemented and unsupplemented groups.

4. Twelve lambs were pair-fed on either a low- or a high-protein diet from birth for 2 I days. Six lambs that were given a large supplement of retinyl palmitate on the Ist day of life had stored significantly less retinol in the liver at 21 days $(P<0.01)$ than six lambs given a somewhat smaller total amount of retinyl palmitate in small daily doses. Lambs given the high-protein diet had significantly greater liver retinol reserves $(P<0.01)$ than lambs given the low-protein diet, with both methods of supplementation.

5. Twelve lambs were pair-fed from birth on a high-protein diet for 2 or 6 days. Lambs that were given retinyl palmitate dissolved in either a low- or a high-protein diet on the Ist day of life had significantly lower liver retinol reserves some $24 \mathrm{~h}$ later $(P<0.0 \mathrm{I})$ than lambs given similar treatments on the $5^{\text {th }}$ day of life. Liver retinol reserves were positively correlated with the protein concentration of the diet at the time of supplementation.

6. Eighteen lambs were pair-fed from birth with either a low- or a high-protein diet. Six pairs were given retinyl palmitate daily and three pairs were given the supplement $48 \mathrm{~h}$ before slaughter. The source of protein was casein. Eight out of nine lambs given the low-protein diet would have died had they not been slaughtered at between 8 and II days of age. The time of supplementation had no significant effect on liver retinol reserves, which were very low, regardless of the dietary protein concentration. Lambs given the high-protein diet retained a significantly greater proportion $(P<0.05)$ of the dietary retinyl palmitate than lambs given the low-protein diet.
\end{abstract}

A close relationship between the level of protein in the diet and the degree of vitamin A retention in the body has been established in a number of species: in the rat by Basu \& De (194I), Arnrich \& Pederson (r956), Esh, Bhattacharya \& Som (r960), Jagannathan \& Patwardhan (I960a,b), Deshmukh, Malathi \& Ganguly (1964) and Vakil, Roels \& Trout (I964); in the chicken by Olsen, Harvey, Hill \& Branion (I959) and Nir \& Ascarelli (r967); in the pig by Friend, Heard, Platt, Stewart \& Turner (196r) and Eaton, Boucher \& Shah (1964); and in the sheep by Anderson, Hubbert, Roubicek \& Taylor (1962). No similar experiments have been reported with the young ruminant and in particular with the milk-fed lamb. In the majority of the experiments reported above, a high intake of protein favoured retention of the dietary vitamin A.

The present experiments had as their aim a study of vitamin A storage when the protein intake was either adequate or well below the optimum for the milk-fed lamb.

* Present address: East Regional Laboratories, PCSIR, Dhanmondi, Dacca, East Pakistan. 
The high-protein diets contained concentrations of protein similar to those of ewe's milk (i.e. $26.5 \%$ of the dry matter; Ling, Kon \& Porter, $196 \mathrm{I}$ ). The effect of the time of supplementation with vitamin $A$, and the effect of the quality of the protein in the diet on the liver retinol reserves (retinol + retinyl esters, expressed as retinol), were also determined.

\section{EXPERIMENTAL}

\section{Animals and their management}

Cross-bred lambs (Border Leicester $\hat{o} \times$ Merino +$) \times$ Dorset Horn $\hat{o}$, were used in all experiments. The lambs were housed in individual metabolism cages as described by Walker \& Faichney (1964a). In Expts 1, 3, 5, 6 and 7, pregnant ewes were confined in pens for some days before parturition and fed ad lib. on a diet of $50: 5^{\circ}(\mathrm{w} / \mathrm{w})$ wheaten and lucerne chaff. The newborn lambs were taken from the ewe before they had suckled, dried and weighed. The birth weights ranged from $2 \cdot 0$ to $7 \cdot 4 \mathrm{~kg}$.

The newborn lambs were given their first feed within $6 \mathrm{~h}$ of birth and, after two feeds of separated colostrum, were allotted to their dietary treatments. Since the lambs in any particular experiment were born over a period of days, or even weeks, it was not always possible to balance the pairs or groups for sex and for birth weight.

The mean daily maximum and minimum temperatures in the animal house during the experimental period were $28^{\circ}$ and $15^{\circ}$ respectively.

\section{Experimental design}

Expt I. Six newborn lambs (three males and three females) were slaughtered within $6 \mathrm{~h}$ of birth and before they had suckled. The retinol content of the livers was determined.

Expt 2. Ten male lambs that had suckled the ewe for between 5 and 7 days were slaughtered. The retinol concentrations in the serum and liver were determined.

Expt 3. Three male newborn lambs were fed $a d$ lib. on a lard-skim-milk diet (diet no. 2) for 28 days. The method of feeding was as described by Walker, Cook $\&$ Jagusch (1967). No supplements of vitamin A or carotene were given. The retinol concentration in the blood serum was determined at weekly intervals, and in the liver at slaughter.

Expt 4. Thirty-six male lambs that had suckled the ewe at pasture for between 5 and 7 days were used. Eighteen were given a low-protein $\operatorname{diet}(\operatorname{diet}$ no. 1 ) and the remainder a high-protein diet (diet no. 2) for an experimental period of 21 days. Six lambs in each group were given the diet unsupplemented with either retinyl acetate or $\beta$ carotene. The remaining twelve lambs in each group were given supplements of either retinyl acetate or $\beta$-carotene at two levels of supplementation (three lambs per treatment). The supplements were either 22.7 or $90.8 \mu \mathrm{g}$ retinyl acetate and 40 or I $60 \mu \mathrm{g}$ all-trans $-\beta$-carotene per $\mathrm{kg}$ live weight per $24 \mathrm{~h}$. The supplements were dissolved in groundnut oil and were given once daily per os immediately after weighing the lamb.

The intakes of retinyl acetate, or $\beta$-carotene, and energy were adjusted once weekly 
to allow for an increase, but not for a decrease, in live weight. The level of intake of gross energy was $210 \mathrm{kcal} / \mathrm{kg}^{0.73} 24 \mathrm{~h}$. The retinol content of the liver was determined at slaughter.

Expt 5. Twelve lambs were used (six males and six females). Lambs of similar live weight were paired at birth and allotted to either a low-protein (diet no. I; groups $A$ and $C$ ) or a high-protein (diet no. 2; groups B and D) diet for an experimental period of 2 I days. Water-miscible retinyl palmitate was given daily dissolved in the milk, or in three feeds on the Ist day of life. Three pairs of lambs (groups A and B) were given the daily dose in the evening feed. The total daily intake of retinyl palmitate and of energy was kept the same for each lamb within a pair, regardless of any differences in live weight that developed after birth. Adjustments in vitamin and energy intake were made daily to allow for an increase, but not for a decrease, in the live weight of the lambs given the low-protein diet. Retinyl palmitate intake was $55^{\circ} \mu \mathrm{g} / \mathrm{kg}$ $24 \mathrm{~h}$ and energy intake was $210 \mathrm{kcal} / \mathrm{kg}^{0} \cdot 7324 \mathrm{~h}$. The other three pairs of lambs (groups $\mathrm{C}$ and $\mathrm{D}$ ) were given their supplement of retinyl palmitate ( $82500 \mu \mathrm{g}$ per lamb) on the ist day, in three consecutive feeds, immediately following the two feeds of cow's separated colostrum.

Expt 6. Five male and seven female lambs (six pairs of twins) were used. All lambs were given three feeds daily. Six of them (three pairs, groups A and B) were fed for 2 days, whilst the other six (three pairs, groups $C$ and $D$ ) were fed for 6 days and then slaughtered. A high-protein diet (diet no. 2) was given to all lambs for the majority of feeds, but the lambs in group A were given a low-protein diet (diet no. I) for three feeds on the Ist day of life, and those in group $\mathrm{C}$ were given the low-protein diet for three feeds on the $5^{\text {th }}$ day of life. The retinyl palmitate supplement was dissolved in the diet and given in three feeds on either the ist or the $5^{\text {th }}$ day of life. The level of intake of retinyl palmitate was $18200 \mu \mathrm{g} / \mathrm{kg} 24 \mathrm{~h}$, and of energy $210 \mathrm{kcal} / \mathrm{kg}^{0.73} 24 \mathrm{~h}$.

Expt 7. Eighteen lambs (ten males and eight females) were pair-fed on either a low-protein (groups A and C) or a high-protein (groups B and D) diet. It was intended that the experimental period should be of 21 days. However, as discussed later, owing to the poor quality of the protein (diets nos. 3 and 4 ), lambs given the low-protein diet survived for between 8 and I d days only. Retinyl palmitate was given to six pairs of lambs (groups A and B) once daily in the evening feed dissolved in the milk. The remaining three pairs of lambs (groups $\mathrm{C}$ and $\mathrm{D}$ ) were given retinyl palmitate in three consecutive feeds approximately $48 \mathrm{~h}$ before slaughter. The total intakes of retinyl palmitate and of energy were controlled within each pair at the same levels as in Expt 5 (groups A and B). The intake of retinyl palmitate $(\mu \mathrm{g} / \mathrm{kg} 24 \mathrm{~h}$ ) by the lambs in groups $C$ and $D$ was the same as that of lambs in groups $A$ and $B$, but the supplement for groups $\mathrm{C}$ and $\mathrm{D}$ was concentrated into three feeds. Four lambs (group $\mathrm{E}$ ) were given the high-protein diet for $2 \mathrm{I}$ days with daily supplements of retinyl palmitate $\left(55^{\circ} \mu \mathrm{g} / \mathrm{kg} 24 \mathrm{~h}\right)$.

\section{Procedure}

Blood samples in all experiments were taken soon after birth and before the first feed, then at weekly intervals $3 \mathrm{~h}$ after the morning feed. The lambs were weighed 
daily $4 \mathrm{~h}$ after the morning feed, and live-weight gain was estimated by a regression analysis of the daily weights.

The effects of the dietary treatments on the storage of retinol in the liver were estimated in Expts 4-7 by an analysis of variance (Steel \& Torrie, 1960).

\section{Diets}

The composition of the experimental diets is given in Table 1 . The protein source in Expts 3-6 was spray-dried skim cow's milk and in Expt 7 it was calcium caseinate (Casinal; Glaxo Laboratories). Glucose and lard were added to supply additional energy, and the total intake of 'hexose equivalent' for each lamb did not exceed

Table r. Constituents and composition of the diets (per Ioo g dry matter); as fed to the lambs, each diet contained $15 \%$ dry matter

\section{Constituent}

Dried skim milk (g)

Calcium caseinate $(\mathrm{g})$

Glucose (g)

Lard (g)

Glyceryl monostearate (g)

Minerals (g)

Crude protein * (g)

Ether extractives (g)

Ash (g)

Nitrogen-free extractives

(by difference) (g)

Energy (kcal)

Protein calories as \% of

total calories

\begin{tabular}{|c|c|c|c|}
\hline \multicolumn{2}{|c|}{ Expts 3-6 } & \multicolumn{2}{|c|}{ Expt 7} \\
\hline Diet no. I & Diet no. 2 & Diet no. 3 & Diet no. \\
\hline I $5 \cdot I$ & $69 \cdot 6$ & - & - \\
\hline- & - & $5 \cdot 6$ & $28 \cdot I$ \\
\hline $32 \cdot 3$ & $x \cdot 8$ & $4 I \cdot 5$ & $25 \cdot 2$ \\
\hline $41 \cdot 7$ & 25.4 & $45 \cdot 7$ & $39 \cdot 5$ \\
\hline $5 \cdot \mathrm{I}$ & $3 \cdot 2$ & - & - \\
\hline $5 \cdot 8$ & - & $7 \cdot 2$ & $7 \cdot 2$ \\
\hline $5 \cdot 7$ & $25 \cdot 9$ & $5^{\cdot I}$ & 25.8 \\
\hline $47 \cdot 2$ & $29 \cdot 8$ & $45 \cdot 7$ & $39 \cdot 5$ \\
\hline $7 \cdot 0$ & 5.5 & $7 \cdot 6$ & $9 \cdot 5$ \\
\hline $40 \cdot 1$ & 38.8 & $4 I \cdot 6$ & $25 \cdot 2$ \\
\hline 627 & 569 & $62 \mathrm{I}$ & 626 \\
\hline $5^{\circ} 0$ & $25^{\circ} 0$ & $5^{\circ} 0$ & $24 \cdot 9$ \\
\hline $1 \times 6.3$ & & & \\
\hline
\end{tabular}

$8.8 \mathrm{~g} / \mathrm{kg}$ mean live weight per $24 \mathrm{~h}$ (Walker \& Faichney, 1964 b). A concentrated mixture which contained lard, glyceryl monostearate and water in the proportions $(w / w)$ of $8: 1: 54$ was homogenized once weekly in a Weir Junior Homogenizer at a pressure of $850 \mathrm{lb} / \mathrm{in}^{2}$ and a temperature of $65^{-70^{\circ}}$. This concentrate formed the basis of diets nos. I and 2. A concentrated mixture which contained calcium caseinate, lard and water in the proportions $(w / w)$ of $1 \cdot 00: 7 \cdot 85: 30 \cdot 00$ was homogenized as above and formed the basis of diets nos. 3 and 4 .

The individual diets were prepared with distilled water every 2 or 3 days and stored at $5^{\circ}$. Mineral mixtures (added to diets nos. I, 3 and 4 ) and vitamin mixtures were added to each diet so that the final composition was similar to that of ewe's milk (Walker \& Faichney, I964a). The mineral mixture that was used initially was similar to that used by Walker \& Faichney ( $1964 a$ ), but, since with the present diets it formed a precipitate that set hard and was difficult to remove from the glass containers in which the diets were stored, it was certain that the lambs would not have received their calculated intakes of mineral matter. It was therefore replaced by the following solution (g): $\mathrm{NaOH}, 9 \cdot 64 ; \mathrm{KOH}$, I I $_{4} 8 ; \mathrm{K}_{2} \mathrm{HPO}_{4}$, I9.5 $_{5} 8 ; \mathrm{Ca}(\mathrm{OH})_{2}, 0.88 ; \mathrm{HCl}, \mathrm{I} 6.98$; 
$\mathrm{MgCl}_{2} .6 \mathrm{H}_{2} \mathrm{O}$, 29.96; citric acid. $\mathrm{H}_{2} \mathrm{O}, 24 \cdot 70 ; \mathrm{KI}, 0.202 ; \mathrm{MnSO}_{4} \cdot{ }_{5} \mathrm{H}_{2} \mathrm{O}$, 0.109; $\mathrm{NaF}, 0.10 \mathrm{I} ; \mathrm{CoCl}_{2} .6 \mathrm{H}_{2} \mathrm{O}, 0.037 ; \mathrm{CuSO}_{4} \cdot{ }_{5} \mathrm{H}_{2} \mathrm{O}, 0.101 ; \mathrm{ZnCl}_{2}, 0.101 ; \mathrm{FeSO}_{4} \cdot 7 \mathrm{H}_{2} \mathrm{O}$, 0.374 ; water to $\mathrm{I} 1$. The mineral solution was added at the rate of $5 \mathrm{ml}$ per roo kcal diet. $\mathrm{CaHPO}_{4}$ was added separately $(393.5 \mathrm{mg} / \mathrm{roo} \mathrm{kcal} \mathrm{diet)}$; it was only slightly soluble and was present as a fine suspension that settled out slowly, but only after prolonged standing.

All lambs were dosed with I $\mathrm{ml}$ of a groundnut-oil solution of ro 000 i.u. ergocalciferol on the 2nd day of life. Aureomycin soluble $(0.45 \mathrm{~g}$; Cyanamid of Great Britain Ltd), which contained chlortetracycline hydrochloride $(25 \mathrm{mg})$, was given daily, dissolved in the milk, to each lamb. A solution which contained $\mathrm{FeSO}_{4}, \mathrm{CuSO}_{4}$ and $\mathrm{CoCl}_{2}$ was added to diet no. 2 to increase the concentration of these metals in the dry matter by $5 \circ \mathrm{ppm} \mathrm{Fe}, 5 \mathrm{ppm} \mathrm{Cu}$ and $0.1 \mathrm{ppm} \mathrm{Co}$.

The lambs in Expts 3, 5, 6 and 7 were bottle-fed in each of the first two feeds with cow's separated colostrum. This fraction was fed as a source of antibodies to protect the lambs against disease, without giving them a source of vitamin A activity. It was assumed that the cow's colostrum would be as likely to contain antibodies against those bacteria present in the animal house as would ewe's colostrum. The colostrum was the first secretion of two newly calved cows. The fat was separated in a cream separator and discarded. The non-fatty fraction, which contained less than $0.1 \%$ fat, was stored in $200 \mathrm{ml}$ portions at $-20^{\circ}$. Each lamb was given two portions of separated colostrum in successive feeds, one from each cow. There was no evidence that the lambs suffered from bacterial infections during the experiments, though an antibiotic was added to the diets to provide additional protection. The lambs were given the experimental diets three times daily at $07.00, \mathrm{I} 4.00$ and $22.00 \mathrm{~h}$ for the subsequent three feeds, and twice daily at 07.00 and $\mathrm{I} 8.00 \mathrm{~h}$ thereafter.

\section{Analytical methods}

Liver and kidney. Samples were stored at $-20^{\circ}$ under nitrogen until analysed for their retinol content. The retinol was extracted according to the method of RöseGottlieb and estimated by the Carr-Price reaction as described by Hausheer, Moor, Nobile, Mueller \& Wagner (1964).

Blood serum. Retinol was determined in I $\mathrm{ml}$ samples stored at $-20^{\circ}$ under nitrogen by a modification of the method of Bessey, Lowry, Brock \& Lopez (1946).

\section{RESULTS}

\section{Live-weight gain}

Mean values, with their standard errors, for the live weights, daily intakes of energy and live-weight gains of the lambs in Expts 3, 4, 5 and 7 are given in Table 2. The mean live weight of the lambs in Expt $6(n=12)$, was $4 \cdot 2 \pm 0.2 \mathrm{~kg}$. Lambs that were fed on the high-protein diets made consistently greater gains than those fed on the lowprotein diets, regardless of whether the protein source was dried skim milk or calcium caseinate. The nutritive value of diet no. $3(\operatorname{Expt} 7)$ was so poor that all lambs lost weight from birth and the majority would have died, had they not been slaughtered 
when their voluntary intake of milk suddenly decreased markedly. The lamb within a pair that was given the high-protein diet (diet no. 4) was slaughtered at the same age. The live-weight gains of lambs given diet no. 4 were much lower than those made by lambs given an equivalent weight of protein in diet no. 2 .

Table 2. Expts 3, 4, 5 and 7. Mean values with their standard errors for the live weight, energy intake and live-weight gain per $24 \mathrm{~h}$ of lambs given diets of different protein content for $2 \mathrm{I}$ days

\begin{tabular}{|c|c|c|c|c|c|c|}
\hline $\begin{array}{c}\text { Expt } \\
\text { no. }\end{array}$ & Group & $\begin{array}{c}\text { Dietary } \\
\text { protein } \\
\text { calories } \\
(\%)\end{array}$ & $\begin{array}{l}\text { No. of } \\
\text { lambs }\end{array}$ & $\begin{array}{l}\text { Live-weight } \\
\text { (kg) }\end{array}$ & $\begin{array}{l}\text { Energy intake } \\
\text { (kcal) }\end{array}$ & $\begin{array}{c}\text { Live-weight } \\
\text { gain } \\
\text { (g) }\end{array}$ \\
\hline \multicolumn{7}{|c|}{ Diets based on dried skim milk } \\
\hline $\begin{array}{l}3^{*} \\
4\end{array}$ & - & $\begin{array}{r}25 \\
5 \\
25\end{array}$ & $\begin{array}{r}3 \\
18 \\
18\end{array}$ & $\begin{array}{l}7 \cdot 2 \pm 0.1 \\
6.0 \pm 0.2 \\
7.5 \pm 0.1\end{array}$ & $\begin{array}{r}1478 \pm 45 \\
764 \pm 40 \\
1006 \pm 33\end{array}$ & $\begin{array}{r}295 \pm 13 \\
25 \pm 4 \\
172 \pm 6\end{array}$ \\
\hline 5 & $\begin{array}{l}\text { A } \\
\text { B } \\
\text { C } \\
\text { D }\end{array}$ & $\begin{array}{r}5 \\
25 \\
5 \\
25\end{array}$ & $\begin{array}{l}3 \\
3 \\
3 \\
3\end{array}$ & $\begin{array}{l}4.6 \pm 0.2 \\
5.1 \pm 0.4 \\
4.0 \pm 0.2 \\
4.7 \pm 0.4\end{array}$ & $\begin{array}{l}640 \pm 31 \\
623 \pm 35 \\
567 \pm 29 \\
567 \pm 29\end{array}$ & $\begin{array}{l}21 \pm 1 \\
97 \pm 6 \\
10 \pm 9 \\
78 \pm 7\end{array}$ \\
\hline \multicolumn{7}{|c|}{ Diets based on calcium caseinate } \\
\hline 7 & $\begin{array}{l}\text { A } \\
\text { B } \\
\text { C } \\
\text { D } \\
\text { E }\end{array}$ & $\begin{array}{r}5 \\
25 \\
5 \\
25 \\
25\end{array}$ & $\begin{array}{l}6 \\
6 \\
3 \\
3 \\
4\end{array}$ & $\begin{array}{l}3.8 \pm 0.2 \\
4.4 \pm 0.1 \\
4.2 \pm 0.1 \\
4.2 \pm 0.3 \\
4.9 \pm 0.4\end{array}$ & $\begin{array}{l}535 \pm 3^{6} \\
553 \pm 27 \\
490 \pm 3^{8} \\
543 \pm 32 \\
650 \pm 50\end{array}$ & $\begin{array}{r}-50 \pm 11 \\
33 \pm 7 \\
-50 \pm 25 \\
38 \pm 3 \\
56 \pm 6\end{array}$ \\
\hline
\end{tabular}

Table 3. Expts I and 2. Mean values with their standard errors and range for the live weight, liver weight and retinol content of the liver and serum of lambs slaughtered before or after suckling the ewe

\begin{tabular}{|c|c|c|c|c|c|}
\hline \multirow[b]{2}{*}{$\begin{array}{c}\text { Age } \\
\text { (days) }\end{array}$} & \multirow[b]{2}{*}{$\begin{array}{l}\text { No. of } \\
\text { lambs }\end{array}$} & \multirow[b]{2}{*}{$\begin{array}{l}\text { Live weight } \\
\text { (kg) }\end{array}$} & \multirow[b]{2}{*}{$\begin{array}{c}\text { Liver weight } \\
\text { (g) }\end{array}$} & \multicolumn{2}{|c|}{ Retinol $(\mu \mathrm{g})$} \\
\hline & & & & Per liver & $\begin{array}{c}\text { Per } 100 \mathrm{ml} \\
\text { serum }\end{array}$ \\
\hline \multicolumn{6}{|c|}{ Expt I } \\
\hline o & 6 & $\begin{array}{l}3.8 \pm 0.3 \\
(3.0-5.0)\end{array}$ & $\begin{array}{c}67 \pm 5 \\
(52-87)\end{array}$ & $\begin{array}{l}21 \pm 8 \\
(5-58)\end{array}$ & $\begin{array}{c}9.9 \pm 0.7^{*} \\
(4.2-19.2)\end{array}$ \\
\hline \multicolumn{6}{|c|}{ Expt 2} \\
\hline $5-7$ & 10 & $\begin{array}{l}4 \cdot 8 \pm 0 \cdot 1 \\
(4 \cdot I-5 \cdot 3)\end{array}$ & $\begin{array}{c}87 \pm 3 \\
(74-101)\end{array}$ & $\begin{array}{l}2655 \pm 472 \\
(507-6008)\end{array}$ & $\begin{array}{l}20 \cdot 1 \pm 2 \cdot 9 \\
(8 \cdot 1-33 \cdot 6)\end{array}$ \\
\hline
\end{tabular}

\section{Liver}

Expts 1 and 2. Mean values for the live weight, liver weight and retinol contents of the liver, and serum, of lambs slaughtered at birth or after they had suckled the ewe for between 5 and 7 days are given in Table 3 . The results reflect the normal variability in vitamin $A$ intake of lambs under grazing conditions. 
Vol. 24

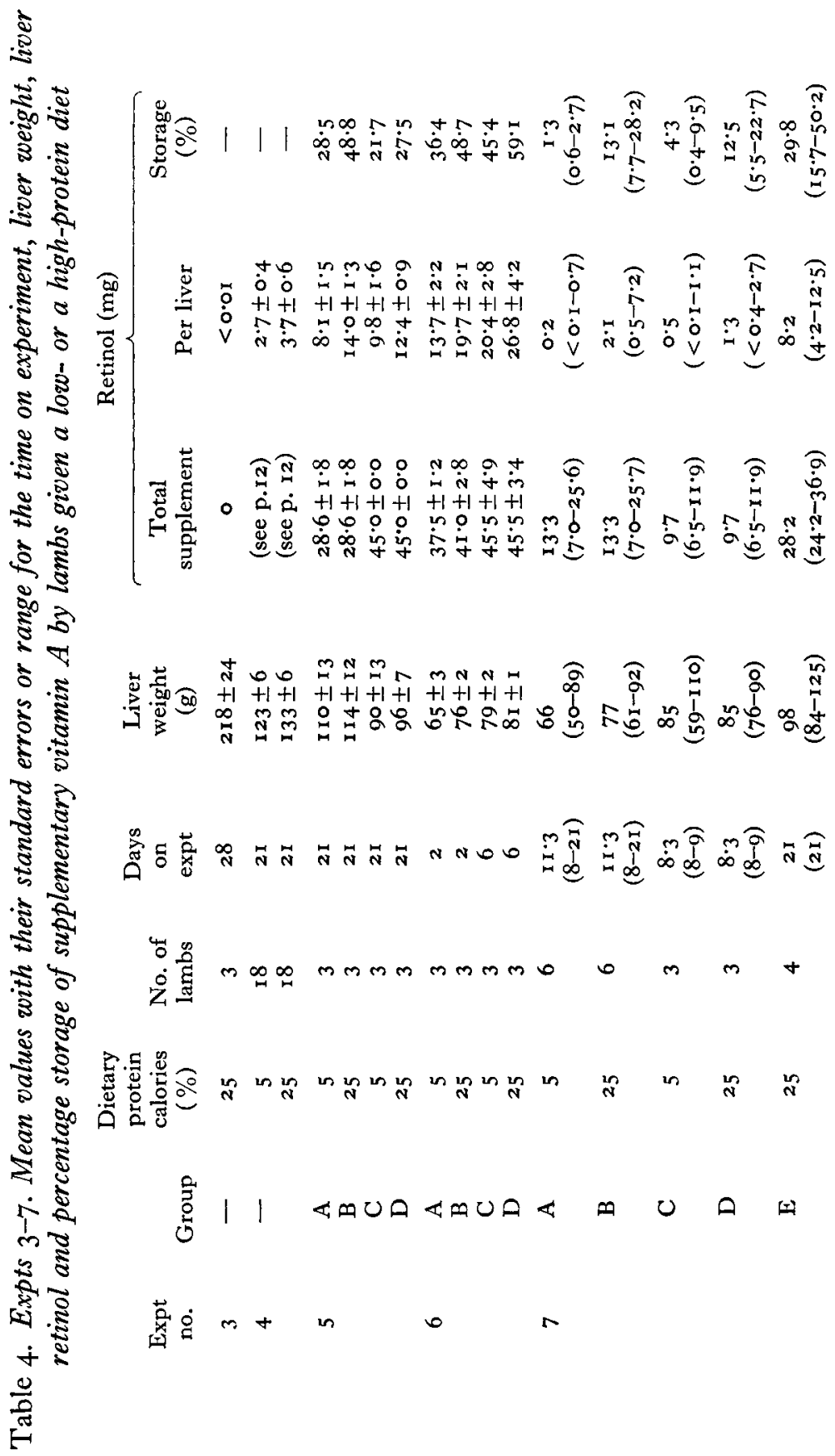


Mean values for the liver weight at slaughter, the total retinyl palmitate supplement (expressed as retinol), total liver retinol and the latter expressed as a percentage of the total supplement are given for Expts $3^{-7}$ in Table 4.

Expt 3. The liver retinol reserves at slaughter of the three lambs fed ad lib. on diet no. 2 without a vitamin A supplement were no less than those of the six lambs slaughtered at birth (Expt I), in spite of the fact that the lambs had trebled their birth weights by 28 days of age. It was apparent that the diet had provided some vitamin $\mathrm{A}$, in an amount sufficient for rapid growth but insufficient to permit substantial storage in the liver. The serum retinol concentrations, measured at weekly intervals, varied from 6.0 to $11.4 \mu \mathrm{g} / 100 \mathrm{ml}$, and there was no significant change in concentration with age.

Expt 4. There were no significant differences in the liver retinol reserves attributable to either the protein content of the diet or supplementation of the diets with either retinyl acetate or $\beta$-carotene. The values given in Table 4 are grouped according to the protein content of the diet without further subdivision. This experiment showed that lambs will grow well on a diet containing $25 \%$ protein calories with lard as the source of fat, but will not grow when the diet provides only $5 \%$ of its total calories as protein. It also demonstrated that when lambs are taken from the ewe at 5-7 days of age they will grow well for $2 \mathrm{I}$ days if fed on a high-protein diet, regardless of whether or not further supplements of retinyl acetate or $\beta$-carotene are given.

Expt 5. Lambs given a high-protein diet with either a large supplement of retinyl palmitate on the rst day of life, or a small daily supplement, had significantly greater $(P<0 \cdot 0 r)$ liver retinol reserves and stored a significantly higher proportion of the supplement $(P<0.01)$ than pair-fed lambs given a low-protein diet.

Lambs given retinyl palmitate daily stored a significantly greater proportion of the supplement $(P<0.01)$ than lambs given the supplement on the ist day of life, regardless of the protein concentration of the diet.

Expt 6. The liver retinol reserves of lambs given the high-protein diet were significantly greater $(P<0.01)$ than those of pair-fed lambs given the low-protein diet, whichever time the supplement was given. At the same dietary protein concentration, all lambs that were supplemented on the $5^{\text {th }}$ day of life had significantly greater liver retinol reserves $(P<0.01)$, and had stored a significantly greater proportion of the supplement $(P<0.01)$ than those given a similar amount of retinyl palmitate on the Ist day of life.

Expt 7. Lambs given diets containing casein as the source of protein were much less efficient in storing dietary retinyl palmitate in the liver than lambs given diets containing skim-milk proteins. The values for percentage storage by lambs given the low-protein diet were particularly low, whether the supplement was given daily (group A) or on a single day some $48 \mathrm{~h}$ before slaughter (group C). All differences in percentage storage between groups given the low- or the high-protein diet were significant $(P<0.01)$, but the differences between groups $\mathrm{A}$ and $\mathrm{C}$, and between $\mathrm{B}$ and $\mathrm{D}$ were not significant. The lambs in group $\mathrm{E}$, which were fed on the highprotein casein diet for 2I days and supplemented daily with retinyl palmitate, had liver retinol reserves that were almost identical with those of lambs in Expt 5 (group A), 
which were given a similar daily intake of retinyl palmitate as a supplement to the low-protein skim-milk diet.

\section{Kidney}

The retinol content of the kidneys of lambs used in Expts 5 and 7 was determined at slaughter. The mean weight was $28 \pm \mathrm{I} g(n=28$; range I9-39), and the total retinol content was $5^{\mathrm{I}} \pm 3 \mu \mathrm{g}$ (range 26-102). There was no significant effect of the protein concentration of the diet on the total kidney retinol content. Kidney retinol reserves did not exceed $0.2 \%$ of the total liver retinol of lambs in Expt 5. In Expt 7 the total liver retinol reserves were very much lower than in Expt 5, but since there was no reduction in the kidney retinol reserves, the kidney retinol represented between 0.2 and $28.7 \%$ of that present in the liver.

\section{Serum}

Mean values for the retinol concentrations in the blood serum of lambs in Expts 5-7 are given in Table 5. There was a significant increase $(P<0.01)$ in the serum retinol concentration between birth and slaughter in all lambs. There were no significant

Table 5. Expts 5-7. Mean values and range for the retinol content of the blood serum $(\mu \mathrm{g} / \mathrm{x} 00 \mathrm{ml})$ of lambs given a low- or a high-protein diet

\begin{tabular}{|c|c|c|c|c|c|c|c|}
\hline \multirow{2}{*}{$\begin{array}{c}\text { Expt } \\
\text { no. }\end{array}$} & \multirow[b]{2}{*}{ Group } & \multirow{2}{*}{$\begin{array}{c}\text { Dietary } \\
\text { protein } \\
\text { calories } \\
(\%)\end{array}$} & \multirow{2}{*}{$\begin{array}{l}\text { No. } \\
\text { of } \\
\text { lambs }\end{array}$} & \multicolumn{4}{|c|}{ Time of sampling (weeks) } \\
\hline & & & & Birth & $\mathbf{I}$ & 2 & 3 \\
\hline \multirow[t]{4}{*}{5} & A & 5 & 3 & $\begin{array}{c}10.5 \\
(4.8-16 \cdot 8)\end{array}$ & $\begin{array}{c}14 \cdot 7 \\
(12 \cdot 0-15 \cdot 9)\end{array}$ & $\begin{array}{c}18 \cdot 9 \\
(16 \cdot 8-20 \cdot 4)\end{array}$ & $\begin{array}{c}23 \cdot 4 \\
(18 \cdot 0-33 \cdot 9)\end{array}$ \\
\hline & B & 25 & 3 & $\begin{array}{c}7 \cdot 2 \\
(5 \cdot 7-9 \cdot 9)\end{array}$ & $\begin{array}{c}18 \cdot 6 \\
(12 \cdot 0-26 \cdot 1)\end{array}$ & $\begin{array}{c}20 \cdot 1 \\
\left(17^{\cdot} 4^{-25} \cdot 2\right)\end{array}$ & $\begin{array}{c}3 I \cdot 5 \\
(2 I \cdot 3-37 \cdot 5)\end{array}$ \\
\hline & C & 5 & 3 & $\begin{array}{c}7 \cdot 2 \\
(5 \cdot 7-9 \cdot 6)\end{array}$ & $\begin{array}{c}15.6 \\
(13.8-18.0)\end{array}$ & $\begin{array}{c}18 \cdot 6 \\
\left(13.8-25^{.2}\right)\end{array}$ & $\begin{array}{c}19.2 \\
(15.0-25.5)\end{array}$ \\
\hline & D & 25 & 3 & $\begin{array}{c}6 \cdot 9 \\
(6 \cdot 6-7 \cdot 2)\end{array}$ & $\begin{array}{c}18 \cdot 0 \\
(14.4-23 \cdot I)\end{array}$ & $\begin{array}{c}21 \cdot 0 \\
(16 \cdot 8-25 \cdot 2)\end{array}$ & $\begin{array}{c}21 \cdot 0 \\
(18 \cdot 9-24 \cdot 6)\end{array}$ \\
\hline \multirow[t]{2}{*}{6} & $\mathrm{~A}, \mathrm{C}$ & 5 & 6 & $\begin{array}{c}10 \cdot 5 \\
(6 \cdot 6-13 \cdot 8)\end{array}$ & $\begin{array}{c}60 \cdot 9^{*} \\
\left(3^{8} \cdot 4^{-87 \cdot 0}\right)\end{array}$ & - & - \\
\hline & $\mathrm{B}, \mathrm{D}$ & 25 & 6 & $\begin{array}{c}I I \cdot 7 \\
(8 \cdot I-I 5 \cdot 0)\end{array}$ & $\begin{array}{c}57 \cdot 0^{*} \\
(25 \cdot 8-90 \cdot 0)\end{array}$ & - & - \\
\hline \multirow[t]{2}{*}{7} & $\mathrm{~A}, \mathrm{C}$ & 5 & $(-)$ & $\begin{array}{c}8.4(9) \\
(4.8-13.8)\end{array}$ & $\begin{array}{c}36 \cdot 9(9) \\
(9 \cdot 9-59 \cdot 7)\end{array}$ & $24.0(\mathrm{I})$ & $19.8(\mathrm{I})$ \\
\hline & $\mathrm{B}, \mathrm{D}, \mathrm{E}$ & 25 & $(-)$ & $\begin{array}{c}\text { II.4 (I } 3) \\
(4 \cdot 2-I 9 \cdot 2)\end{array}$ & $\begin{array}{c}33.6(13) \\
(18.0-60.0)\end{array}$ & $\begin{array}{c}36.6(5) \\
\left(19.5-57^{\circ} \circ\right)\end{array}$ & $\begin{array}{c}27 \cdot 3(5) \\
\left(17 \cdot 4-37^{\circ} \cdot 2\right)\end{array}$ \\
\hline
\end{tabular}

differences between the serum retinol concentrations at 3 weeks within a particular experiment. The mean serum retinol concentrations of lambs given diets that contained casein as the source of protein (Expt 7) were consistently higher at 7 days of age than the corresponding values for lambs given diets that contained skim milk (Expt 5).

The high serum retinol concentrations at slaughter of lambs used in Expt 6 may be explained by the very high intakes of retinyl palmitate, and by the relatively short period $(24 \mathrm{~h})$ between the time of supplementation and the time of slaughter. 


\section{DISCUSSION}

In all species so far studied, the feeding of diets high in protein has led to a greater retention of dietary vitamin $\mathrm{A}$ in the liver than occurs with diets low in protein. The experiments with the milk-fed lamb reported in this paper showed that, regardless of the time or duration of vitamin A supplementation or of the quality of the protein in the diet, the liver retinol reserves of unsuckled lambs were greater with the diets of higher protein content. However, the proportion of the dietary vitamin A that was retained in the liver was not constant but was affected by the time and duration of supplementation, by the amount of vitamin A given, and by the quality of the protein in the diet.

\section{Expt 5}

Lambs given retinyl palmitate in small daily doses for 2 I days retained a significantly greater proportion of the supplement than lambs given a somewhat larger total weight of retinyl palmitate on a single day at the beginning of the experimental period. This difference was most marked with lambs given the high-protein diet.

Moore (1957) and Mitchell (1962) have reported that the rate of depletion of liver vitamin A reserves, and the efficiency with which dietary vitamin A is stored in the liver, are not related to the daily requirement of the animal, but are functions of the liver vitamin A concentration at any particular time, or the size of the dietary supplement. Thus, the higher the liver reserve the greater is the rate of depletion, and the larger the dietary supplement the smaller is the percentage stored in the liver. It would seem that when lambs were given the supplement of retinyl palmitate on the ist day of life a greater amount of retinol may have been stored in the liver soon after dosing than was measured at slaughter some $2 \mathrm{I}$ days later, and that this initial reserve decreased more rapidly than was necessary simply to provide the daily retinol requirement of the lamb. This conclusion is supported by the results obtained in Expt 6, where the amounts of retinyl palmitate given to the lambs, and the times of dosing, were almost the same as in Expt 5 (groups C and D), but where the liver retinol reserves and the percentage stored were considerably higher at slaughter some $24 \mathrm{~h}$ later.

\section{$\operatorname{Expt} 6$}

It is generally assumed that the reduction in liver retinol reserves, and the poor storage of dietary vitamin A that results from diets of low-protein content, are a relatively long-term effect, a matter of days and weeks rather than of hours (cf. Basu \& De, 1941; Jagannathan \& Patwardhan, I960a; Vakil et al. 1964; Nir \& Ascarelli, 1967). The results obtained in the present study suggest that the amount of retinyl palmitate absorbed and retained in the liver is controlled by the amount of protein in the diet at the time of supplementation. Lambs that were given supplements of retinyl palmitate dissolved in a low-protein diet for only three feeds $(24 \mathrm{~h})$ had significantly lower liver retinol reserves, when slaughtered some $24 \mathrm{~h}$ later, than lambs given similar amounts of retinyl palmitate dissolved in a high-protein diet. Since both groups of lambs were given high-protein diets before and after the short period of 
supplementation, it was hardly possible that any of the lambs were protein-deficient in the accepted sense, though immediate biochemical changes must have occurred.

To study the effect of the age of the lamb, in the immediate postnatal period, on the efficiency with which dietary retinyl palmitate is stored in the liver was the main purpose of Expt 6. During the Ist day of life the newborn lamb normally ingests colostrum that has a higher protein content and higher vitamin A activity than milk. In addition, it is known that during the first $24-48 \mathrm{~h}$ of life certain proteins may be absorbed intact from the digestive tract (Brambell, 1958). Thus the absorption and storage of retinyl palmitate by the lamb during the Ist day of life should be optimal, and better than at any subsequent age. However, the results in our experiment did not support this hypothesis. The retention of dietary retinyl palmitate in the liver was greater at 5 days of age than on the ist day of life.

It is not known whether this effect of age also applies to the normal lamb suckling the ewe, or whether the colostral proteins allow a more efficient absorption and retention of vitamin A than was observed in this experiment, with diets containing the proteins of cow's milk.

\section{Expt 7}

It has been shown by Fraps (1946), James \& ElGindi (1953) and by Berger, Rechcigl, Loosli \& Williams (1962) that, when diets are given that contain a protein of low nutritive value, there is a reduction in the proportion of the dietary vitamin A that is absorbed and stored in the liver. This effect of protein quality becomes more pronounced when the total intake of protein is at or below the minimum protein requirement.

The majority of the lambs in Expt 7 that were fed on the diets containing casein as the source of protein had lower liver retinol reserves, and were more inefficient in the storage of the supplementary retinyl palmitate, than the lambs in Expt 5 given diets that contained all milk proteins. It is known that the amino acid content of milk proteins differs from that of casein, and that casein is deficient in certain essential amino acids required by the rat (Osborne \& Mendel, I9I6). It is apparent that casein is also a poor-quality protein for the lamb. The relatively high serum retinol concentrations noted at 7 days (cf. Table 5), when compared with those of lambs given diets nos. I and 2, suggest either that the retinyl palmitate had been absorbed but was not retained by the liver, or that the rate of absorption was so reduced that the higher concentrations to be expected soon after dosing (cf. Expt 6; Table 5) had not diminished some $\mathrm{I} 6 \mathrm{~h}$ later when samples were taken. It was certain that the lambs were truly protein-deficient when fed on diet no. 3 , and to a more severe degree than those lambs given the low-protein diet no. I. It would seem that they were also protein-deficient when fed on diet no. 4 , though to a less pronounced extent.

We wish to thank Roche Products Pty. Ltd, Sydney, for gifts of retinyl acetate, retinyl palmitate, $\beta$-carotene and ergocalciferol, and Cyanamid Australia Pty. Ltd for a gift of Aureomycin. 


\section{REFERENCES}

Anderson, T. A., Hubbert, F., Roubicek, C. B. \& Taylor, R. E. (I962). F. Nutr. 78, 341.

Arnrich, L. \& Pederson, D. J. (1956). Fedn Proc. Fedn Am. Socs exp. Biol. r5, 212.

Basu, N. M. \& De, N. K. (I94I). Sci. Cult. 6, 672.

Berger, S., Rechcigl, M., Loosli, J. K. \& Williams, H. H. (1962). F. Nutr. 77, 174.

Bessey, O. A., Lowry, O. H., Brock, M. J. \& Lopez, J. A. (1946). F. biol. Chem. 166, I77.

Brambell, F. W. R. (1958). Biol. Rev. 33, 488 .

Deshmukh, D. S., Malathi, P. \& Ganguly, J. (1964). Biochem. F. 90, 98.

Eaton, H. D., Boucher, W. B. \& Shah, P. C. (1964). F. Nutr. 82, 343.

Esh, G. C., Bhattacharya, S. \& Som, J. M. (1960). Ann. Biochem. exp. Med. 20, I 5.

Fraps, G. S. (1946). Archs Biochem. 10, 485.

Friend, C. J., Heard, C. R. C., Platt, B. S., Stewart, R. J. C. \& Turner, M. R. (1961). Br. F. Nutr. I5, $23 \mathrm{I}$.

Hausheer, W., Moor, H., Nobile, S., Mueller, P. B. \& Wagner, H. (1964). In Schweiz. Lebensmittelbuch. Vol. 1, 5th ed., p. 655. Bern: Eidg Drucksachen-und Material Centrale.

Jagannathan, S. N. \& Patwardhan, V. N. (1960a). Indian Y. med. Res. 48, 775.

Jagannathan, S. N. \& Patwardhan, V. N. (I960b). Indian $\mathscr{~}$. med. Res. 48, 785.

James, W. H. \& ElGindi, I. M. (1953). F. Nutr. 51, 97.

Ling, E. R., Kon, S. K. \& Porter, J. W. G. (196r). In Milk: the Mammary Gland and its Secretion. Vol 2., p. I95. [S. K. Kon and A. T. Cowie, editors.] New York: Academic Press Inc.

Mitchell, H. H. (1962). In Comparative Nutrition of Man and Domestic Animals. Vol. 1, p. 482 . New York: Academic Press Inc.

Moore, T. (1957). Vitamin A. New York: Elsevier Publishing Co.

Nir, I. \& Ascarelli, I. (1967). Br. F. Nutr. 21, 167.

Olsen, E. M., Harvey, J. D., Hill, D. C. \& Branion, H. D. (1959). Poult. Sci. 38, 942.

Osborne, T. B. \& Mendel, L. B. (I916). F. biol. Chem. 26, r.

Steel, R. G. D. \& Torrie, J. H. (1960). Principles and Procedures of Statistics. Toronto: McGraw-Hill Book Co. Inc.

Vakil, U. K., Roels, O. A. \& Trout, M. (1964). Br. F. Nutr. 18, 217.

Walker, D. M., Cook, L. J. \& Jagusch, K. T. (1967). Br. F. Nutr. 21, 275

Walker, D. M. \& Faichney, G. J. (1964a). Br. F. Nutr. 18, 187.

Walker, D. M. \& Faichney, G. J. (1964b). Br F. Nutr. 18, 209. 